\begin{tabular}{|c|c|c|}
\hline \multirow{3}{*}{$\begin{array}{r}\text { Case Reports in } \\
\text { Gastroenterology }\end{array}$} & \multirow{2}{*}{\multicolumn{2}{|c|}{ Case Rep Gastroenterol 2016;10:417-422 }} \\
\hline & & \\
\hline & $\begin{array}{l}\text { DOI: } 10.1159 / 000448072 \\
\text { Publisned onine.: August 9, } 2016\end{array}$ & $\begin{array}{l}\text { (C) } 2016 \text { The Author(s) } \\
\text { Published by S. Karger AG, Basel } \\
\text { www.karger.com/crg }\end{array}$ \\
\hline & \multicolumn{2}{|c|}{$\begin{array}{l}\text { This article is licensed under the Creative Commons Attribution-NonCommercial } 4.0 \\
\text { International License (CC BY-NC) (http://www.karger.com/Services/OpenAccessLicense). } \\
\text { Usage and distribution for commercial purposes requires written permission. }\end{array}$} \\
\hline
\end{tabular}

\title{
Delayed Viral Clearance after 6-Week Treatment with Peginterferon Plus Ribavirin in a Patient with Chronic Hepatitis C Virus Genotype 1b
}

\author{
Akira Sato $^{\mathrm{a}}$ Toshiya Ishii $^{\mathrm{a}}$ Kayo Adachi $^{\mathrm{a}}$ Hideaki Takahashi $^{\mathrm{a}}$ \\ Fumiaki Sano $^{\mathrm{b}}$ Nobuyuki Matsumoto ${ }^{c}$ \\ ${ }^{a}$ Division of Gastroenterology, Department of Internal Medicine, St. Marianna University \\ School of Medicine Yokohama City Seibu Hospital, Yokohama, Japan; ${ }^{\circ}$ Division of \\ Hematology and Oncology, Department of Internal Medicine, St. Marianna University \\ School of Medicine Yokohama City Seibu Hospital, Yokohama, Japan; 'Division of \\ Gastroenterology and Hepatology, Department of Internal Medicine, St. Marianna \\ University School of Medicine, Kawasaki, Japan
}

\section{Keywords}

Hepatitis C - Delayed viral clearance - Spontaneous viral clearance - Peginterferon - Ribavirin . HLA $\cdot$ IL28B

\begin{abstract}
Following interferon-based therapy for chronic hepatitis $C$, the negativity of hepatitis $C$ virus RNA is essential to achieve viral clearance at the end of treatment. We report a case of clearance of chronic hepatitis $C$ virus infection following early discontinuation (at 6 weeks) of peginterferon plus ribavirin therapy, without negativity for hepatitis $C$ virus RNA during the treatment period. The patient was a 76 -year-old Japanese male infected with hepatitis $C$ virus genotype $1 \mathrm{~b}$ and TT of IL28B rs8099917. Hepatitis C virus RNA remained positive at persistently low levels for more than 2 months after the cessation of therapy and became negative at 7 months after the discontinuation of therapy. Spontaneous clearance of hepatitis $C$ virus RNA can occur following antiviral failure in patients with persistently low viral loads, and viro-
\end{abstract}

KARGER
Akira Sato

Division of Gastroenterology, Department of Internal Medicine

St. Marianna University School of Medicine Yokohama City Seibu Hospital

1197-1 Yasashicho Asahi-ku, Yokohama 241-0811 (Japan)

E-Mail asato@marianna-u.ac.jp 


\section{Case Reports in Gastroenterology}

Case Rep Gastroenterol 2016;10:417-422

(c) 2016 The Author(s). Published by S. Karger AG, Basel www.karger.com/crg

Sato et al.: Delayed Viral Clearance after 6-Week Treatment with Peginterferon Plus Ribavirin in a Patient with Chronic Hepatitis C Virus Genotype $1 \mathrm{~b}$

logical follow-up is therefore necessary in chronic hepatitis $C$ virus infection, even after antiviral failure.

\section{Introduction}

Chronic hepatitis C virus (HCV) infection is a major worldwide cause of liver-related deaths, including those caused by cirrhosis and hepatocellular carcinoma. The eradication of HCV using interferon-based treatment improves liver-related mortality and reduces the risk of hepatocellular carcinoma development. Recently, interferon-free direct-acting antiviral therapy was used, which showed an excellent rate of HCV eradication among patients with chronic HCV genotype $1 \mathrm{~b}$, including those with prior interferon-based treatment failure [1]. However, interferon-based therapy is still a treatment option [2], and negativity for HCV RNA at the end of antiviral treatment (end-of-treatment response; ETR) is essential to achieve the viral clearance of chronic infection [3]. Although delayed viral clearance after the completion of 24-48 weeks of interferon-based therapy is rarely reported, such a situation has not been observed among patients with the early discontinuation of therapy. Here, we report a case of HCV clearance at 7 months after a 6-week treatment with peginterferon (pegIFN) plus ribavirin (RBV).

\section{Case Report}

A 76-year-old Japanese male (height, $161 \mathrm{~cm}$; weight, $63 \mathrm{~kg}$ ) with chronic HCV genotype $1 \mathrm{~b}$ infection had initiated treatment with pegIFN $\alpha-2 \mathrm{~b}$ plus RBV. Previously, he had been followed up for inactive chronic hepatitis for 15 years, with alanine aminotransferase (ALT) levels $<40 \mathrm{IU} / \mathrm{l}$, which had fluctuated from 40 to $140 \mathrm{IU} / \mathrm{l}$ for a year before the initiation of the latest treatment regimen. His medical history included hypertension, hyperuricemia, and resistant gastroesophageal reflux disease, which were being treated with nifedipine, candesartan cilexetil, allopurinol, and lansoprazole for more than 5 years. Pretreatment liver biopsy showed grade 1 inflammation and stage 1/4 fibrosis. Laboratory examinations (table 1) revealed the following biochemical levels: ALT, $129 \mathrm{IU} / \mathrm{l} ;$ albumin, $4.3 \mathrm{~g} / \mathrm{dl} ; \gamma$-glutamyl transpeptidase, $72 \mathrm{IU} / \mathrm{l}$; platelet count, $23.6 \times 10^{4} / \mu \mathrm{l}$, and $\alpha$-fetoprotein, $4.9 \mathrm{ng} / \mathrm{ml}$. Hepatitis $\mathrm{C}$ viral load was $5.3 \mathrm{log} \mathrm{IU} / \mathrm{ml}$. Antibody to human immunodeficiency virus and antinuclear antibodies were negative. Genetic studies revealed TT of IL28B (rs8099917) and human leukocyte antigen (HLA)-DRB1*01:01/08:03. After the initiation of therapy, he reported a loss of appetite at week 2 and complained of anxiety, irritability, insomnia, and poor concentration at week 3. Although daily etizolam before sleep was started, he experienced poor appetite, taste disorder, and weight loss of $2 \mathrm{~kg}$ from the initiation of therapy. Therefore, sulpiride was added, and the RBV dose was reduced from 800 to $600 \mathrm{mg}$ per day because of anemia. However, symptoms did not subside with a further weight loss of $1 \mathrm{~kg}$ and the progression of anemia; thus, the RBV dose was reduced to $400 \mathrm{mg} /$ day. Nonetheless, the symptoms persisted, and he reported depression at week 6 , which prompted treatment discontinuation. Following this, the symptoms slowly but gradually subsided, and he recovered after 5 weeks. Meanwhile, the HCV RNA load decreased to weakly positive, with measured values of less than $1.2 \mathrm{log} \mathrm{IU} / \mathrm{ml}$ at week 4, which persisted at this level until 12 days after the discontinuation of treatment (fig. 1). Then, the load gradually increased to $2.6 \mathrm{log} \mathrm{IU} / \mathrm{ml}$ and $4.3 \mathrm{log} \mathrm{IU} / \mathrm{ml}$ at 7-10 and 19 weeks after discontinuation, respectively. Concurrently, 
Sato et al.: Delayed Viral Clearance after 6-Week Treatment with Peginterferon Plus Ribavirin in a Patient with Chronic Hepatitis C Virus Genotype 1b

serum ALT levels, which had persisted at levels of less than $34 \mathrm{IU} / \mathrm{l}$ after the discontinuation of treatment, increased to $44 \mathrm{IU} / \mathrm{l}$. A posttreatment ultrasound exam revealed a 1.0-cm bladder tumor, which was diagnosed by urinary cytology as class $\mathrm{V}$, and the patient was treated by transurethral resection of the bladder tumor (TUR-BT) at week 26 of discontinuation. Histological examination revealed low-grade, noninvasive papillary urothelial carcinoma. Serum ALT had normalized (16 IU/l) at 1 week before TUR-BT, and HCV RNA was found to be negative at 11 days after surgery ( 28 weeks after the discontinuation of antiviral therapy), which has been maintained along with low levels $(<25 \mathrm{IU} / \mathrm{l})$ of ALT for more than 4 years.

\section{Discussion}

This patient showed an unusual and unique clinical course of delayed viral clearance despite only 6 weeks of pegIFN plus RBV therapy, without the achievement of HCV RNA negativity. There are relatively few reports of delayed viral clearance among patients with nonETR and those with relapse after pegIFN plus RBV therapy; all these patients had completed 24-48 weeks of therapy, and almost all had genotype 2 or 3 and were aged $<60$ years [4-6]. Compared with those cases, our patient was unique in terms of being infected with HCV genotype 1b, older, and treated for only 6 weeks without achieving ETR. Although the mechanism underlying delayed viral clearance remains unknown, we speculate two possibilities for this patient. One is an immunological modification due to surgical stress caused by TUR$\mathrm{BT}$, and the other is a delayed effect of pegIFN plus RBV therapy. It has been reported that surgical stress or invasive treatment can sometimes induce the clearance of HCV RNA [7, 8], but this is not applicable to this case because it is quite unlikely that HCV RNA with 4.3 log copies/ml was eliminated within 11 days after TUR-BT. Furthermore, although HCV RNA was not examined, the normalization of serum ALT had already occurred before TUR-BT. Therefore, we alternatively consider the immunological effect induced by pegIFN plus RBV therapy. Chronic infection with HCV is characterized by HCV-specific T cell dysfunction, and $\mathrm{T}$ cell function is considered to play an essential role in the elimination of the virus [9]. Although it is controversial whether pegIFN plus RBV therapy restores $\mathrm{T}$ cell function, the marked restoration of HCV-specific CD8 T cells was observed from 1 month after treatment in patients with a sustained viral response [10], and a correlation between the restoration of HCV-specific CD8+ T-cell function and early/sustained viral response [11] has been reported. In this case, HCV RNA rapidly decreased after treatment, although the levels remained positive at $<1.2 \mathrm{log} \mathrm{IU} / \mathrm{ml}$ at week 4 , and the low levels of viral load persisted for at least 10 weeks after the discontinuation of therapy, suggesting immunological recovery from HCV infection. Furthermore, the mild elevation of ALT at 19 weeks could be considered as the T cell response against increased HCV RNA. This phenomenon is well known in patients with chronic hepatitis B virus (HBV) infection, in whom ALT flare occurs with a preceding increase in HBV DNA, often resulting in continuous virus suppression. The immunological response observed in this phenomenon is also well understood [12]. In our patient, although the elevation of ALT was mild, a similar mechanism was presumed.

This patient had a genetic background of HLA-B1*01:01 and TT of IL28B rs8099917. The cellular immune responses coordinated by CD4 and CD8 T cells are genetically predetermined by the hosts' HLA molecules. In addition, the IL28B gene encodes an innate interferon. Recently, several studies have revealed that the class II DRB1*01:01 HLA allele and the $\mathrm{C}$ and T alleles of IL28B (rs12979860 and rs8099917, respectively) are associated with 
Sato et al.: Delayed Viral Clearance after 6-Week Treatment with Peginterferon Plus Ribavirin in a Patient with Chronic Hepatitis C Virus Genotype $1 \mathrm{~b}$

the spontaneous clearance of HCV [13-15]. Furthermore, HLA-DRB $1 * 01$ is suspected to be associated with delayed viral clearance after pegIFN plus RBV therapy [4]. Therefore, the genetic background of this patient may be related to the viral clearance after treatment discontinuation.

In conclusion, interferon-based therapy remains a viable treatment option for chronic $\mathrm{HCV}$ infection, and virological follow-up is necessary even for patients with non-ETR, particularly for those with persistent low viral loads after treatment.

\section{Statement of Ethics}

Informed consent was obtained from the patient prior to the publication of this study.

\section{Disclosure Statement}

The authors have no competing interest to declare.

\section{References}

1 Mizokami M, Yokosuka O, Takehara T, Sakamoto N, Korenaga M, Mochizuki H, Nakane K, Enomoto H, Ikeda F, Yanase M, Toyoda H, Genda T, Umemura T, Yatsuhashi H, Ide T, Toda N, Nirei K, Ueno Y, Nishigaki Y, Betular J, Gao B, Ishizaki A, Omote M, Mo H, Garrison K, Pang PS, Knox SJ, Symonds WT, McHutchison JG, Izumi N, Omata M: Ledipasvir and sofosbuvir fixed-dose combination with and without RBV for 12 weeks in treatment-naive and previously treated Japanese patients with genotype 1 hepatitis C: an open-label, randomised, phase 3 trial. Lancet Infect Dis 2015;15:645-653.

-2 European Association for the Study of the Liver: EASL recommendations on treatment of hepatitis C 2015. J Hepatol 2015;63:199-236.

-3 Ghany MG, Strader DB, Thomas DL, Seeff LB: Diagnosis, management, and treatment of hepatitis C: an update. Hepatology 2009;49:1335-1374.

4 Denis J, Rautou PE, Lambare B, Herbert S, Auray-Cartier V, Asselah T: Chronic hepatitis C: Viral clearance several months after discontinuation of therapy in two non-responders. Infection 2007;35:197-200.

5 Annicchiarico BE, Siciliano M, Avolio AW, Grillo RL, Bombardieri G: A 5-year prospective study of the late resolution of chronic hepatitis C after antiviral therapy. Aliment Pharmacol Ther 2007;25:10391046.

6 Cho SH, Lee SW, Choi SR, Han SY, Roh MH, Lee JH, Jang JS, Baek YH, Kim SY: Delayed viral clearance of chronic hepatitis $C$ in patients after treatment failure. Gut Liver 2011;5:110-114.

7 Yoshikawa M, Morimoto Y, Shiroi A, Yoshiji H, Kuriyama S, Fukui H: Spontaneous elimination of serum HCV-RNA after total gastrectomy for early gastric cancer in a patient with chronic hepatitis C. Am J Gastroenterol 2001;96:922-923.

8 Minami T, Tateishi R, Shiina S, Fujiwara N, Mikami S, Sato M, Uchino K, Enooku K, Asaoka Y, Kondo Y, Yoshida H, Koike K: Spontaneous clearance of serum hepatitis C virus RNA during the clinical course of hepatocellular carcinoma in patients with chronic hepatitis C. Hepatol Res 2014;44:E32-E37.

-9 Schmidt J, Blum HE, Thimme R: T-cell responses in hepatitis B and C virus infection: similarities and differences. Emerg Microbes Infect 2013;3:e15.

10 Caetano J, Martinho A, Paiva A, Pais B, Valente C, Luxo C: Differences in hepatitis C virus (HCV)-specific CD8 T-cell phenotype during pegylated alpha interferon and ribavirin treatment are related to response to antiviral therapy in patients chronically infected with HCV. J Virol 2008;82:7567-7577.

11 Larrubia LR, Lokhande MU, Moreno-Cubero E, García-Garzón S, Miquel J, Parra-Cid T, GonzálezPraetorious A, Perna C, Lázaro A, Sanz-de-Villalobos E: HCV-specific CD8+ cell detection at week 12 of chronic hepatitis $\mathrm{C}$ treatment with PEG-interferon-a2b/ribavirin correlates with infection resolution. Cell Immunol 2013;286:31-38.

$\$ 12$ Chang ML, Liaw YF: Hepatitis B flares in chronic hepatitis B: pathogenesis, natural course, and management. J Hepatol 2014;61:1407-1417. 
Sato et al.: Delayed Viral Clearance after 6-Week Treatment with Peginterferon Plus Ribavirin in a Patient with Chronic Hepatitis C Virus Genotype $1 \mathrm{~b}$

13 McKiernan SM, Hagan R, Curry M, McDonald GS, Kelly A, Nolan N, Walsh A, Hegarty J, Lawlor E, Kelleher D: Distinct MHC Class I and II alleles are associated with hepatitis Cviral clearance, originating from a single source. Hepatology 2004;40:108-114.

-14 Fitzmaurice K, Hurst J, Dring M, Rauch A, McLaren PJ, Günthard HF, Gardiner C, Klenerman P; Irish HCV Research Consortium; Swiss HIV Cohort Study: Additive effects of HLA alleles and innate immune genes determine viral outcome in HCV infection. Gut 2015;64:813-819.

15 Ikezaki H, Furusyo N, Hiramine S, Ura K, Mitsumoto-Kaseida F, Takayama K, Shimizu M, Toyoda K, Ogawa E, Kainuma M, Murata M, Hayashi J: Association of IL28B rs8099917 genotype and female sex with spontaneous clearance of hepatitis $\mathrm{C}$ virus infection: a Japanese cross-sectional study. Arch Virol 2016;161:641-648.

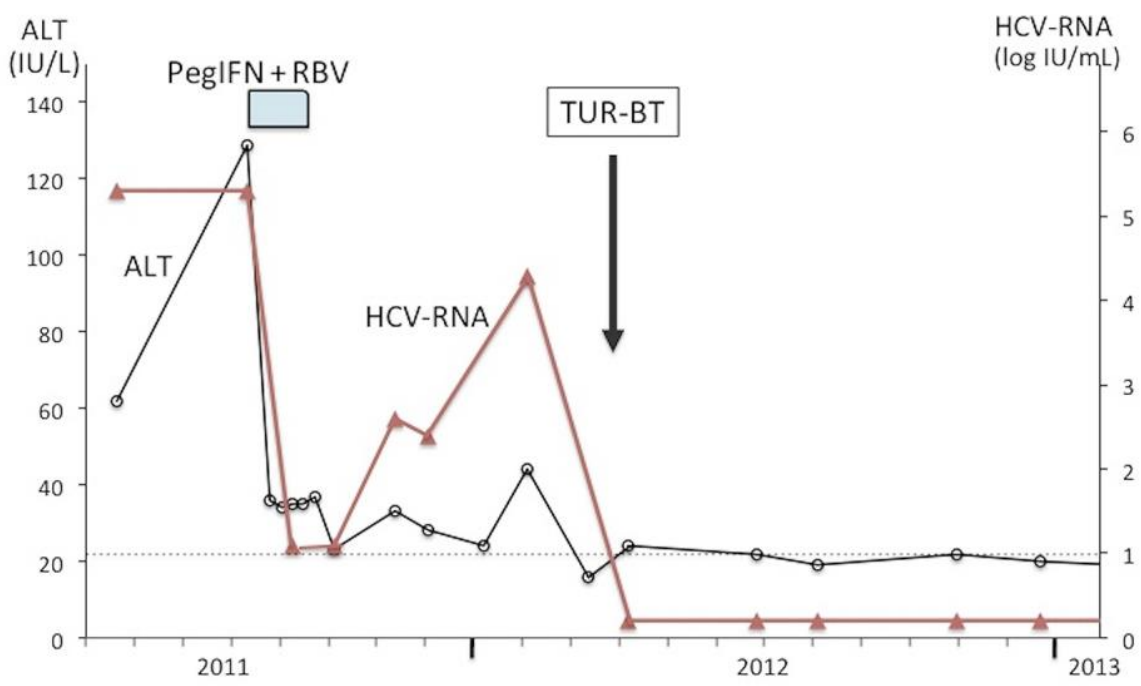

Fig. 1. Clinical course of the patient in the present study. 
Sato et al.: Delayed Viral Clearance after 6-Week Treatment with Peginterferon Plus Ribavirin in a Patient with Chronic Hepatitis C Virus Genotype $1 \mathrm{~b}$

Table 1. Laboratory data before treatment with pegIFN plus RBV

\begin{tabular}{lclrll}
\hline WBC & $7,300 / \mu \mathrm{l}$ & ALP & $347 \mathrm{IU} / \mathrm{l}$ & HCV genotype & $1 \mathrm{~b}$ \\
$\mathrm{Hb}$ & $16.0 \mathrm{~g} / \mathrm{dl}$ & $\gamma$-GTP & $38 \mathrm{IU} / \mathrm{l}$ & RNA load & $5.3 \mathrm{log} \mathrm{IU} / \mathrm{ml}$ \\
$\mathrm{Hct}$ & $47.1 \%$ & TP & $8.3 \mathrm{~g} / \mathrm{dl}$ & ISDR & mixed type $(6,1)$ \\
$\mathrm{Plt}$ & $24.5 \times 10^{4} / \mu \mathrm{l}$ & ALB & $4.3 \mathrm{~g} / \mathrm{dl}$ & Core $70 \mathrm{AA}$ & competitive type \\
$\mathrm{PT}$ & $114.0 \%$ & $\mathrm{TC}$ & $203 \mathrm{mg} / \mathrm{dl}$ & Core $91 \mathrm{AA}$ & wild type \\
T.Bil & $0.6 \mathrm{mg} / \mathrm{dl}$ & $\mathrm{UA}$ & $5.7 \mathrm{mg} / \mathrm{dl}$ & & \\
D.Bil & $0.1 \mathrm{mg} / \mathrm{dl}$ & UN & $13.8 \mathrm{mg} / \mathrm{dl}$ & IL-28B & T/T \\
& & & & rs8099917 & \multirow{2}{*}{ B $1 * 01: 01 / 08: 03$} \\
AST & $36 \mathrm{IU} / \mathrm{l}$ & Cre & $0.98 \mathrm{mg} / \mathrm{dl}$ & HLA DR & \\
ALT & $43 \mathrm{IU} / \mathrm{l}$ & Glucose & $95 \mathrm{mg} / \mathrm{dl}$ & & \\
LDH & $193 \mathrm{IU} / \mathrm{l}$ & AFP & $4.9 \mathrm{ng} / \mathrm{ml}$ & & \\
\hline
\end{tabular}

WBC = White blood cell count; $\mathrm{Hb}=$ hemoglobin; Hct = hematocrit Plt = platelet PT $=$ prothrombin time; T.Bil = total bilirubin; D.Bil = direct bilirubin; AST = aspartate aminotransferase; $\mathrm{LDH}=$ lactate dehydrogenase; ALP = alkaline phosphatase; $\gamma$-GTP $=\gamma$-glutamyl transferase; $\mathrm{TP}=$ total protein; $\mathrm{Alb}=$ albumin; TC $=$ total cholesterol; $\mathrm{UA}=$ uric acid; $\mathrm{UN}=$ urea nitrogen; $\mathrm{Cre}=$ creatinine; $\mathrm{AFP}=\alpha$-fetoprotein; ISDR = interferon sensitivity-determining region; Core 70AA = core 70 amino acid; IL-28B = interleukin-28B; HLA = human leukocyte antigen. 